\title{
Wear Properties Enhancement of Aluminium Alloy with Addition of Nano Alumina
}

R. Surendran

Assistant professor, Government College of Engineering

Salem

N. Manibharathi

PG scholar, GovernmentCollege of Engineering

Salem.

India

\section{A. Kumaravel}

Professor and Head K.S.R. College of Technology,

The wear Behaviour of LM 25 reinforced with nano $\mathrm{Al}_{2} \mathrm{O}_{3}$, a nanocomposite with increased wear resistance is investigated. Strength and Stiffness is manufactured by Stir casting. Four different specimens of reinforced nanocomposite have been manufactured with the addition of nano alumina consisting of 99\% LM 25+1\% Nano $\mathrm{Al}_{2} \mathrm{O}_{3}, 98.5 \% \mathrm{LM}$ $25+1.5 \%$ Nano $\mathrm{Al}_{2} \mathrm{O}_{3}, 98 \% \mathrm{LM} 25+2 \%$ Nano $\mathrm{Al}_{2} \mathrm{O}_{3}, 97.5 \% \mathrm{LM} 25+2.5 \%$ Nano $\mathrm{Al}_{2} \mathrm{O}_{3}$ along with pure LM 25 aluminium alloy.Dry sliding wear tests were performed using PIN-ON-DISC tribometer apparatus and the wear performances were investigated under both loading and unloading conditions. Reinforcement of nano-sized particles with aluminium matrix yields superior mechanical and physical properties and changes morphology of nano-composites. The wear reduction is due to strong bond formation between $\mathrm{Al}$ and $\mathrm{Al}-\mathrm{Al}_{2} \mathrm{O}_{3}$ nano composites. The results show that the addition of nanopowder in varying proportions influences the increased wear performance of the aluminium alloy and the maximum wear reduction is obtained with the addition of $2.5 \%$ Nano $\mathrm{Al}_{2} \mathrm{O}_{3}$, when compared with the results of pure LM25and other al- $\mathrm{Al}_{2} \mathrm{O}_{3}$ composites. The wear test is performed by sliding the fabricated Nanocomposite cylindrical pins against the steel disc at a constant sliding velocity in gravity loading and loading condition (i.e)500g load.

Keywords: stir casting, enhancing wear properties,loading condition, unloaded condition,PIN on Disc tribometer Experimentation, $\mathrm{Al}_{-} \mathrm{Al}_{2} \mathrm{O}_{3}$ composite.

\section{INTRODUCTION}

Pure $\mathrm{Al}$ is among the most interesting model materials for processing because of its unique micro structural and mechanical features (1) the wear resistance of pure Aluminium processed by various processing parameters(2) is studied. Aluminium alloys have been used as a matrix alloy in producing metal based composites. The main cause for its use in composite manufacturing is low density of aluminium (3) and the reason for its usage in the industries is because of its increased properties in composites such as low density, high strength and stiffness, high specific modulus, very good wear resistance, low coefficient of thermal expansion, high damping capacity and excellent high temperature properties. These properties have led to numerous applications of these composites in different industries such as automobile applications, aerospace and aeronautical, military and nuclear power (6) Wear Behaviour of aluminium matrix composites depends on strength of the interface between matrix and reinforcement particle.

In this study the composites Material (LM 25-2.5\%

Received: June 2015, Accepted: September 2015

Correspondence to: Assistant professor, R. Surendran,

Government College of Engineering, Salem, Tamil

Nadu, India

E-mail: surengce@gmail.com

doi:10.5937/fmet1701083S

(c) Faculty of Mechanical Engineering, Belgrade. All rights reserved
$\mathrm{Al}_{2} \mathrm{O}_{3}$ ) exhibited improved wear strength in comparison with the other tested samples. The wear test is performed by a pin-on-Disk tribometer wear-testing apparatus. Aluminium LM 25 alloy with $2.5 \%$ of reinforcement of nano alumina particulates has the highest wear strength among the tested samples. The al-reinforced composites shows the best performance with the improvement in the wear resistance with the addition of nano particles upto a certain limit. There is a gradual reduction in the wear rates of all the specimens in the same testing conditions.

\section{EXPERIMENTAL PROCEDURE}

The material selected for this is LM25 reinforced with Nano Alumina of $40 \mathrm{~nm}$ of purity $99.5 \%$ obtained from MKImpex Corp,Canada. The chemical composition of LM 25 is shown in Table 1.

Table: 1 Composition of LM 25

\begin{tabular}{|c|c|}
\hline MATERIALS & $\%$ \\
\hline Copper & $0.2 \max$ \\
\hline Magnesium & $0.20-0.60$ \\
\hline Silicon & $6.5-7.5$ \\
\hline Iron & $0.5 \max$ \\
\hline Manganese & $0.3 \max$ \\
\hline Nickel & $0.1 \max$ \\
\hline Zine & $0.1 \max$ \\
\hline Lead & $0.1 \max$ \\
\hline Tin & $0.05 \max$ \\
\hline Titanium & $0.2 \max$ \\
\hline Aluminium & Remainder \\
\hline
\end{tabular}


The samples are made by stir casting method by varying the weight percentage of nano alumina which is shown in Table 2.

\section{Table: 2 Samples composition with varying percentage of} Nano Alumina

\begin{tabular}{|l|c|c|c|}
\hline \multicolumn{1}{|c|}{ Material } & $\begin{array}{c}\mathrm{LM} 25 \\
(\mathrm{~g})\end{array}$ & $\begin{array}{c}\text { Nano } \\
\mathrm{Al}_{2} \mathrm{O}_{3}(\mathrm{~g})\end{array}$ & Total $(\mathrm{g})$ \\
\hline Pure LM 25 & 1000 & - & 1000 \\
\hline $\begin{array}{l}\text { 99\%LM 25+1\% } \\
\text { Nano } \mathrm{Al}_{2} \mathrm{O}_{3}\end{array}$ & 990 & 10 & 1000 \\
\hline $\begin{array}{l}98.5 \% \mathrm{LM} \\
25+1.5 \% \text { Nano } \\
\mathrm{Al}_{2} \mathrm{O}_{3}\end{array}$ & 985 & 15 & 1000 \\
$\begin{array}{l}98 \% \mathrm{LM} \mathrm{25+2 \%} \\
\mathrm{Nano} \mathrm{Al}_{2} \mathrm{O}_{3}\end{array}$ & 980 & 20 & 1000 \\
\hline $\begin{array}{l}\text { 97.5\%LM } \\
25+2.5 \% \text { Nano } \\
\mathrm{Al}_{2} \mathrm{O}_{3}\end{array}$ & 975 & 25 & 1000 \\
\hline
\end{tabular}

\subsection{Manufacturing of aluminium using stir casting process:}

The stir casting setup consists of conical shaped graphite crucible, used for fabrication of amcs, as it withstands high temperature. The use of graphite crucible is that graphite will not react with aluminium at hot temperatures. This crucible is placed in a muffle which is made up of high ceramic alumina. The coil acts as the heating element is Kanthol-A1. This type of furnace is known as resistance heating furnace. It can work up to $900^{\circ} \mathrm{C}$ reach within $45 \mathrm{~min}$. A commercial casting-grade aluminium alloy was employed as the matrix material while the $\mathrm{Al}_{2} \mathrm{O}_{3}$ nano particles with average particle sizes of $40 \mathrm{~nm}$ were used as the reinforcements. The alloy along with the different composition as mentioned in table 2 was melted in a resistance furnace at $720{ }^{\circ} \mathrm{C}$, and then degassed for 10 min with argon gas through a graphite lance.

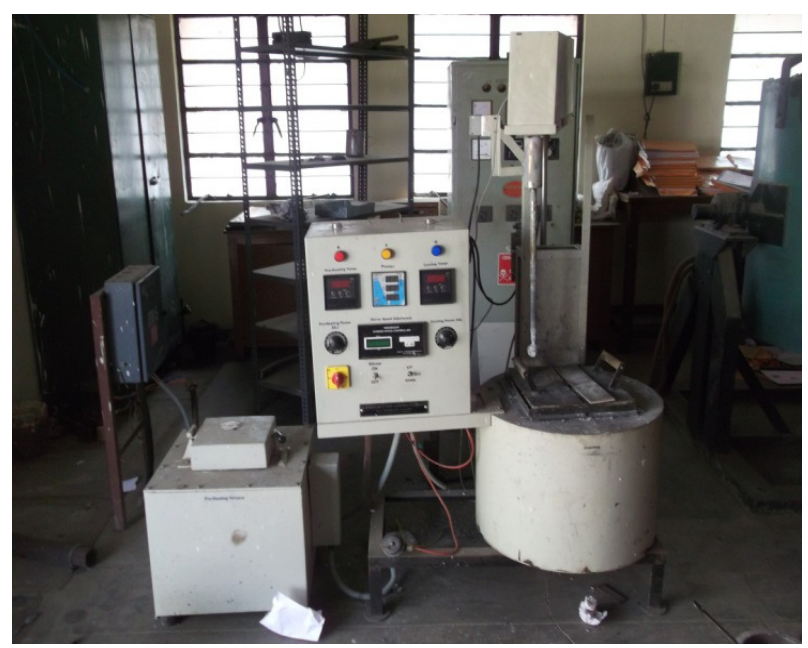

Figure 1. stir casting setup

The composition is mixed using an electromagnetic stirrer (EMS) device to obtain a uniform distribution of the particles. The current was varied from 30 and $70 \mathrm{~A}$ while the voltage was kept constant and equal to $220 \mathrm{~V}$. $\mathrm{Mg}$ was added to the melt in order to increase the wettability between the matrix and the reinforcements. The temperature was lowered to convert the liquid into semisolid slurry. The slurry as immediately poured into the die cavity and squeezed during the solidification.

\subsection{Pin on disc tribometer wear test}

Sliding wear tests were conducted in pin-on-disc wear testing apparatus under the gravity loading condition and loaded condition of $500 \mathrm{~g}$ at a fixed sliding speed of $1.85 \mathrm{~m} / \mathrm{s}$ against EN31 steel disc for a sliding distance of $9.25 \mathrm{~m}$. The pin samples were $60 \mathrm{~mm}$ in length and 6 $\mathrm{mm}$ in diameter. The pins used in this research were produced as a cylinder with a diameter of $6 \mathrm{~mm}$ and height of $2 \mathrm{~cm}$. The Disk used in this research was made of steel. The wear test was performed without load i.e. with the effect of gravity. At the end of each stage, the surface of steel disc is cleaned and washed by ethanol.

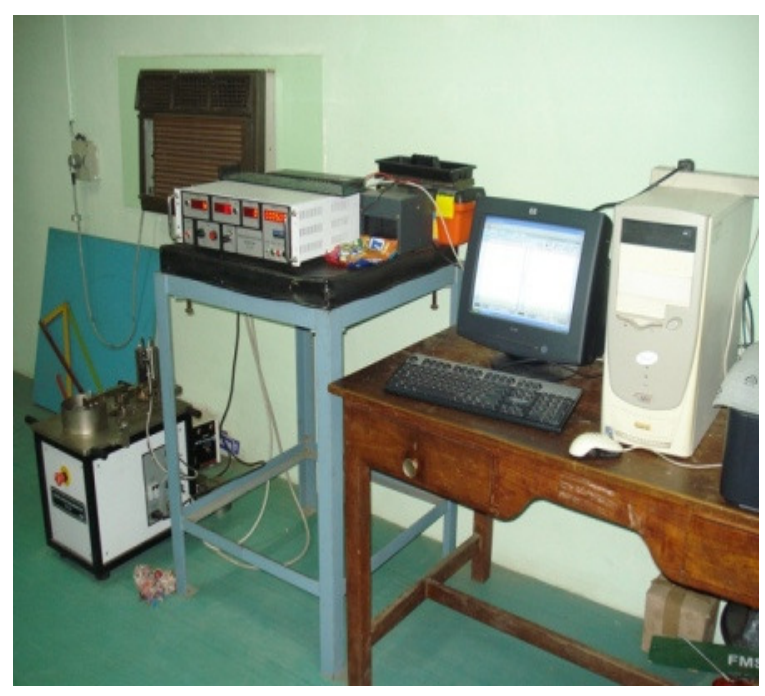

Figure 2. Pin on disc tribometer wear testing setup

The surfaces of the pin sample are made as convex shape without any minor fins using emery paper prior to the test in order to ensure effective contact with the steel disc. During sliding, the load is applied to the specimen through cantilever mechanism and the specimens brought in intimate contact with the rotating disc during loading condition at a track radius of $40 \mathrm{~mm}$. The pin is made to slide against the EN 31 steel disc for about five minutes at dry lubrication conditions. The corresponding wear of the pin against the time is plotted graphically. During the cantilever assembly which holds the specimen is connected to a weight holder in which can carry a maximum of $1000 \mathrm{~g}$ load. After the proper loading condition the specimen is allowed to slide at specific RPM.From the graph it is evident that the values of wear for the particular composition can be attained in micrometers.

\section{RESULTS}

The volumetric wear rates of Aluminium LM 25 and Reinforced composites are plotted against the time to the wear in micrometers. It is immediately apparent that there is consistent improvement in wear resistance with increasing amounts of reinforcement.

The parameters such as sliding speed, sliding distance, time of sliding should be fed into the pin on a 
disc tribometer setup manually.After completion of wear testing graph consisting of Wear vs data points are obtained from the digital computer with graph plotting software which is connected to pin on disc tribometer apparatus digitally.

Table: $\mathbf{3}$ Wear sample specification and conditions.

\begin{tabular}{|l|c|}
\hline Pin length & $60 \mathrm{~mm}$ \\
\hline Pin diameter & $\phi=6 \mathrm{~mm}$ \\
\hline Load & No load condition \\
\hline Track diameter & $40 \mathrm{~mm}$ \\
\hline Sliding speed & $1.85 \mathrm{~m} / \mathrm{s}(885 \mathrm{rpm})$ \\
\hline Temperature & Room temperature \\
\hline Moisture & $<30 \%$ \\
\hline
\end{tabular}

The parameters such as sliding speed,sliding distance, time of sliding should be fed into the pin on disc tribometer setup manually.After completion of the wear testing graph consisting of wear vs data points are obtained from the digital computer with graph plotting software which is connected to pin on disc tribometer apparatus digitally.

\subsection{WEAR BEHAVIOUR UNDER THE EFFECT OF GRAVITY}

\subsubsection{Graphical representation of wear behaviour:} LM 25 Aluminium Alloy

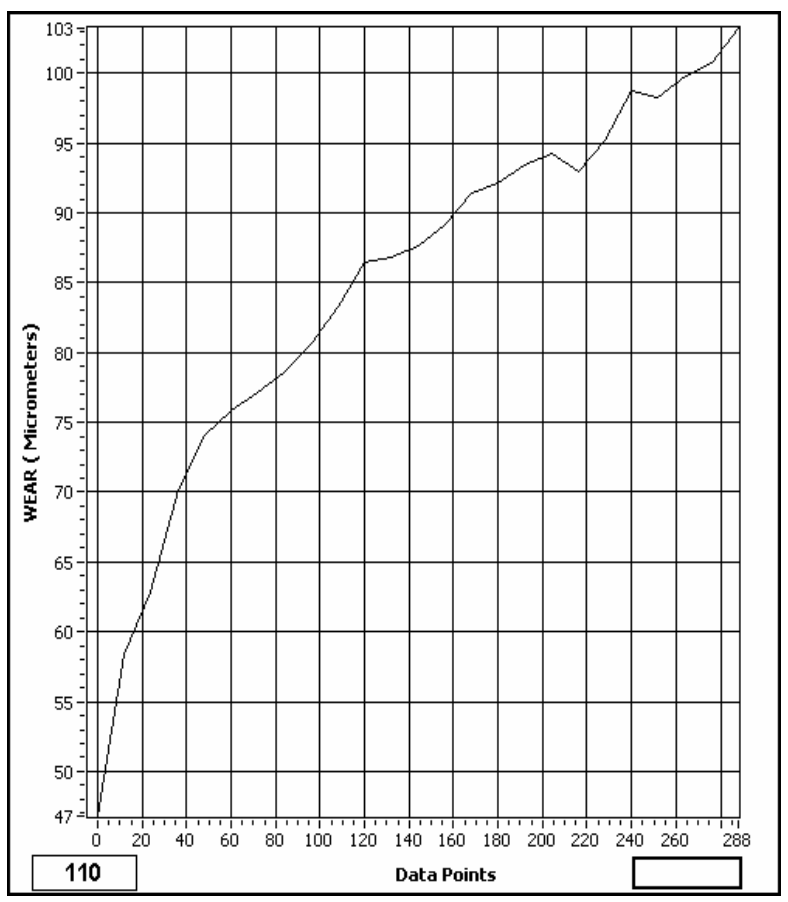

Figure 3. Wear $(\mu \mathrm{m})$ vs Data Points

The above figure shows the wear Behaviour of LM25 aluminium alloy against the data points. It wears 110micrometers after sliding against EN31 steel Disc for about $300 \mathrm{~s}$ at a sliding velocity of $1.85 \mathrm{~m} / \mathrm{s}$.

\subsubsection{Graphical representation of wear behaviour: $99 \% \mathrm{LM} 25+1 \% \mathrm{Nano}_{\mathrm{Al}_{2} \mathrm{O}_{3}}$}

This graph showed the wear Behaviour of 99\%LM 25 aluminium alloy $+1 \%$ nano $\mathrm{Al} 2 \mathrm{O} 3$ versus the data points. It wears for a maximum of 100 micrometers.

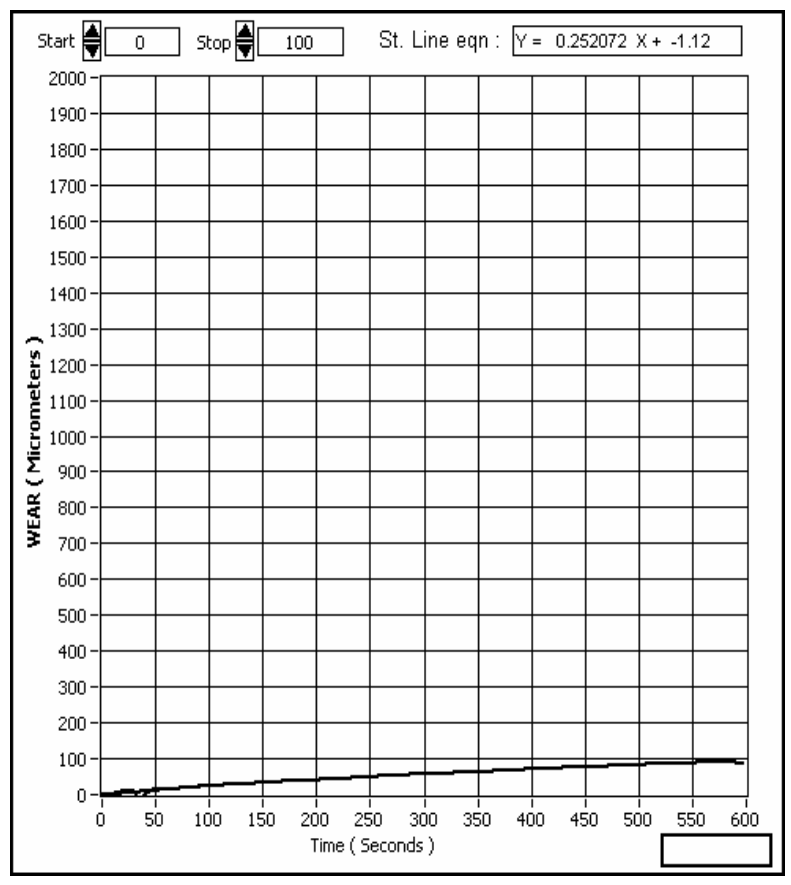

Figure 4. Wear $(\mu \mathrm{m})$ Vs Data Points

\subsubsection{Graphical representation of wear behaviour: $98.5 \% \mathrm{LM} 25+1.5 \% \mathrm{Nano}^{\mathrm{Al}_{2} \mathrm{O}_{3}}$}

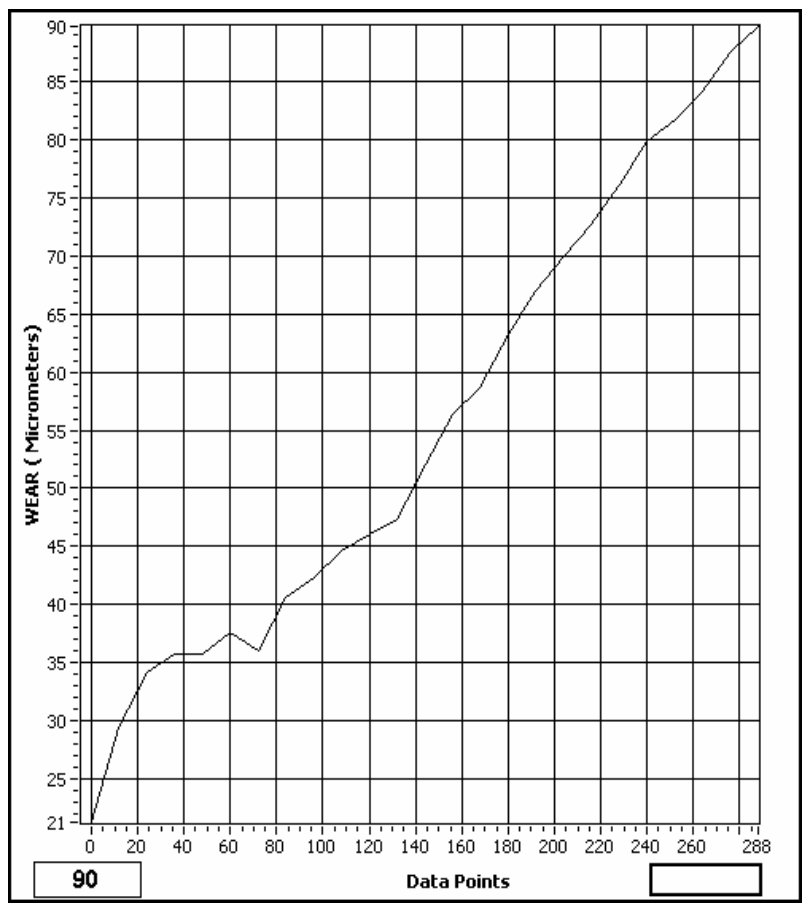

Figure 5. Wear $(\mu \mathrm{m})$ vs Data Points

This graph showed the wear Behaviour of $98.5 \% \mathrm{LM}$ 25 aluminium alloy $+1.5 \%$ nano $\mathrm{Al}_{2} \mathrm{O}_{3}$ versus the data points. It wears for a maximum of 90 micrometers for the sliding distance of $9.25 \mathrm{~m}$.

\subsubsection{Graphical representation of wear behaviour: 98.5\%LM 25+1.5\% $\mathrm{Nano}_{\mathrm{Al}_{2} \mathrm{O}_{3}}$}

This graph showed the wear Behaviour of 98.5\%LM 25 aluminium alloy $+1.5 \%$ nano $\mathrm{Al}_{2} \mathrm{O}_{3}$ versus the data points. It wears for a maximum of 90 micrometers for the sliding distance of $9.25 \mathrm{~m}$. 


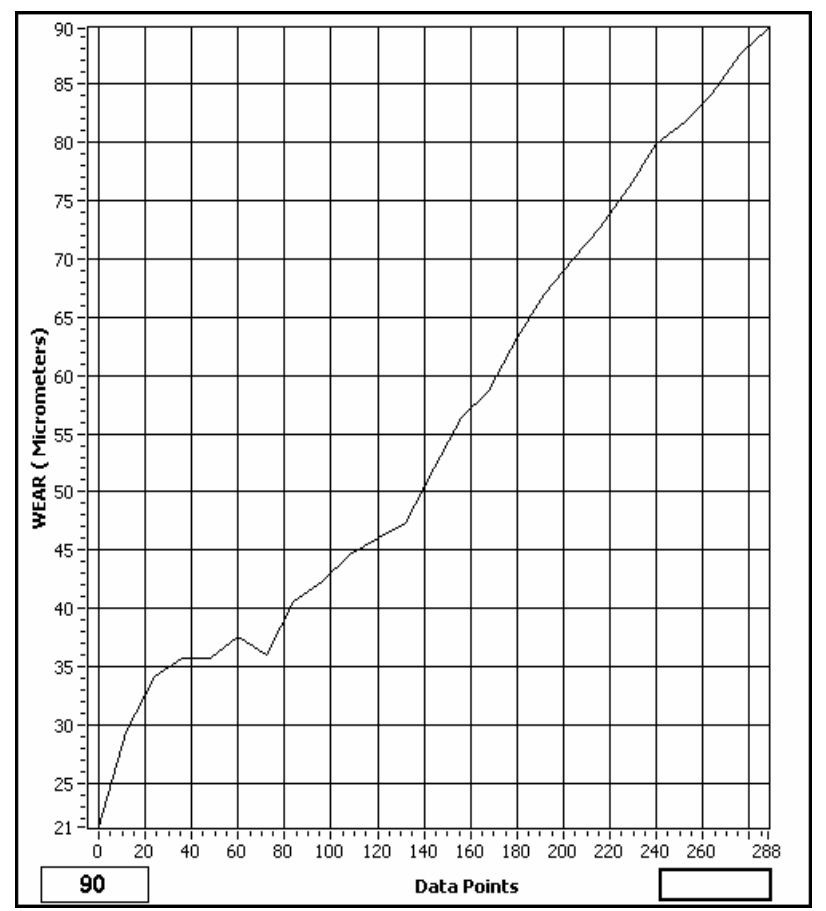

Figure 6. Wear $(\mu \mathrm{m})$ vs Data Points

\subsubsection{Graphical representation of wear behaviour: $98 \%$ LM 25+2\% Nano $\mathrm{Al}_{2} \mathrm{O}_{3}$}

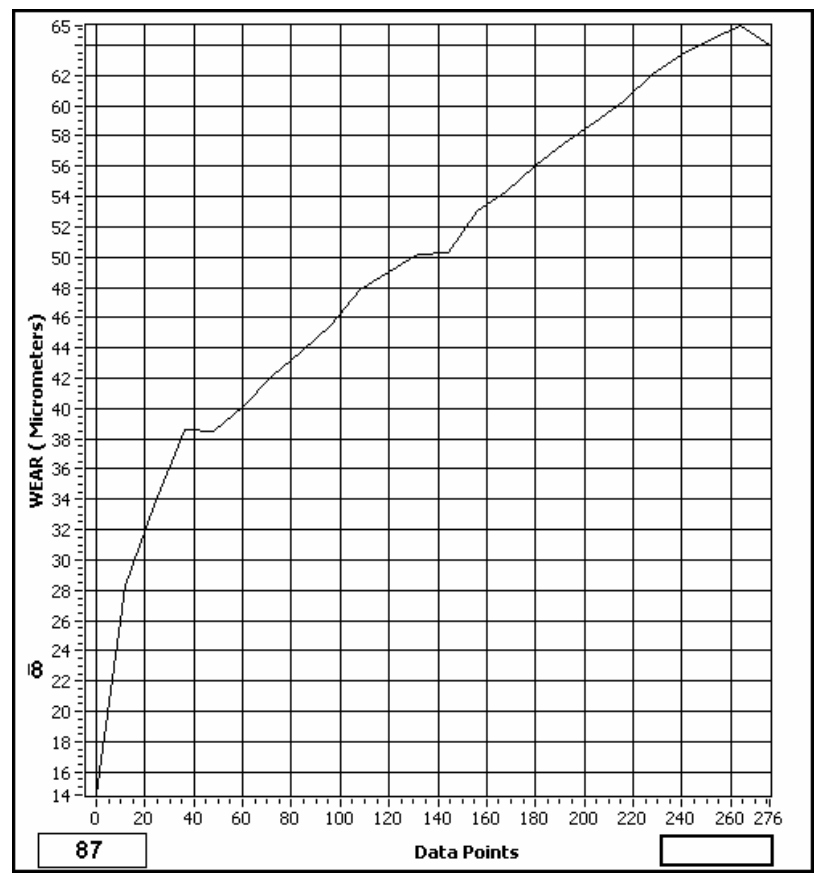

Figure 7. Wear $(\mu \mathrm{m})$ vs Data Points

It was observed that the wear86ehavior of $98 \% \mathrm{LM}$ 25 aluminium alloy $+2 \%$ nano Alumina versus the data points. It wears at 87 micrometers.

\subsubsection{Graphical representation of wear behaviour : 97.5\%LM 25+2.5\% Nano $\mathrm{Al}_{2} \mathrm{O}_{3}$}

This graph plotted the wear behaviour of 97.5\%LM 25 aluminium alloy $+2.5 \%$ nano $\mathrm{Al}_{2} \mathrm{O}_{3}$ versus the data points. It shows a wear of 71 micrometers .The pure LM 25 wears $71 \mu \mathrm{m}$ in a time span of 300 seconds.

\subsection{WEAR BEHAVIOUR UNDER LOADING CONDITIONS:}

3.2.1 Graphical representation of wear behaviour: pure LM 25 Aluminium alloy under load $500 \mathrm{~g}$ :

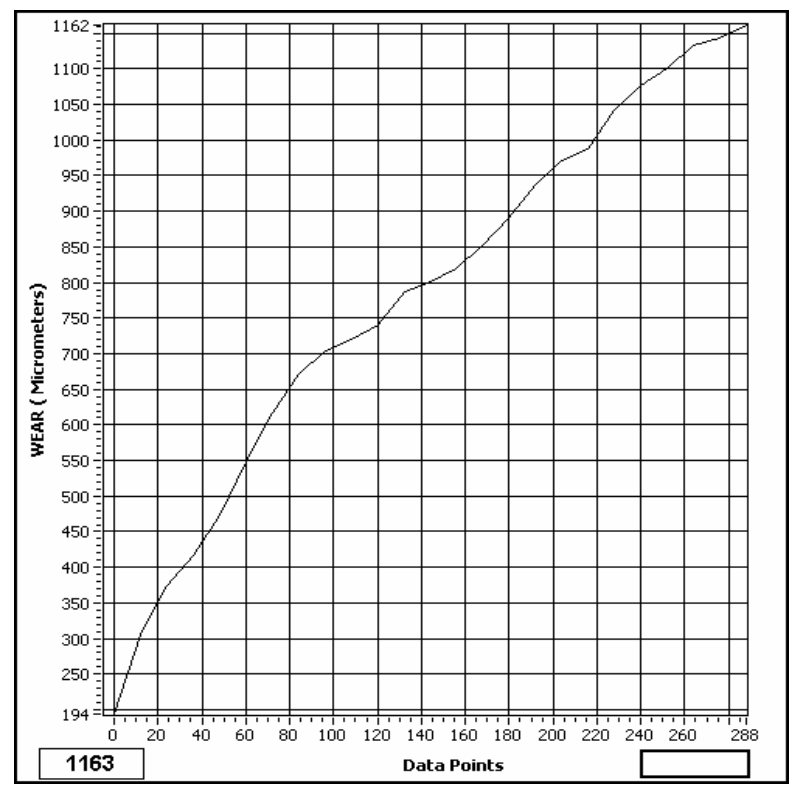

Figure 8. Wear $(\mu \mathrm{m})$ vs Data Points

This graph plotted the wear Behaviour of LM 25 aluminium alloy versus the data points. It shows a wear of 1163 micrometers . The pure LM25 wears $1163 \mu \mathrm{m}$ in a time span of 300 seconds.

\subsubsection{Graphical representation of wear behaviour:} 99\%LM 25+1\% Nano $\mathrm{Al}_{2} \mathrm{O}_{3}$ under load 500g:

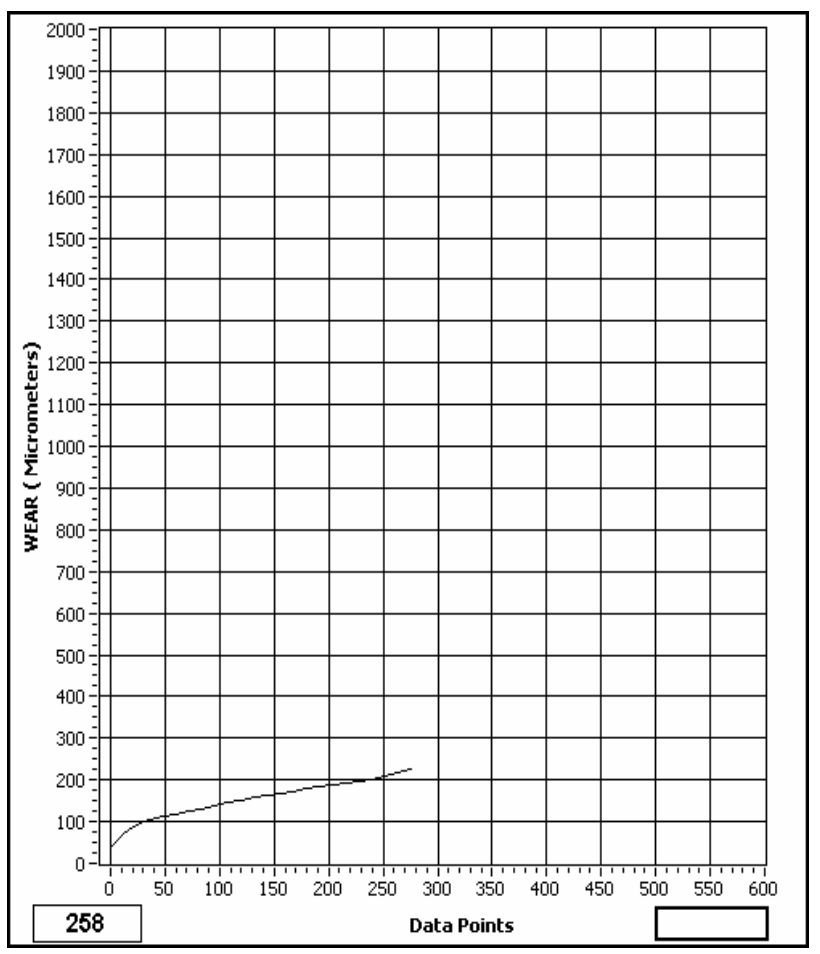

Figure 9. Wear $(\mu \mathrm{m})$ Vs Data Points

This graph plotted the wear Behaviour of $99 \%$ LM 25 aluminium alloy $+1 \%$ nano $\mathrm{Al}_{2} \mathrm{O}_{3}$ versus the data points. It shows a wear of 258 micrometers . 
3.2.3 Graphical representation of wear behaviour: 98.5\%LM 25+1.5\% Nano $\mathrm{Al}_{2} \mathrm{O}_{3}$ under load $500 \mathrm{~g}$ :

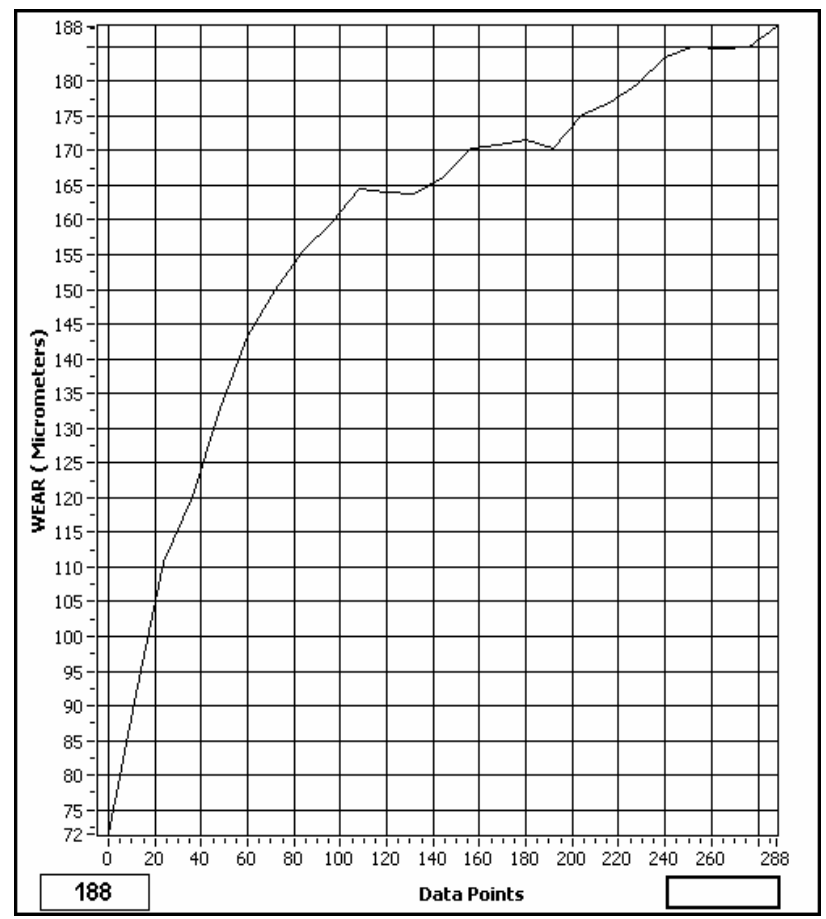

Figure 10. Wear $(\mu \mathrm{m})$ vs Data Points

This graph plotted the wear Behaviour of 98.5\%LM 25 aluminium alloy $+1 \%$ nano $\mathrm{Al}_{2} \mathrm{O}_{3}$ versus the data points. It shows a wear of 188 micrometers.

\subsubsection{Graphical representation of wear behaviour:}

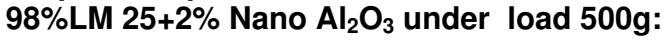

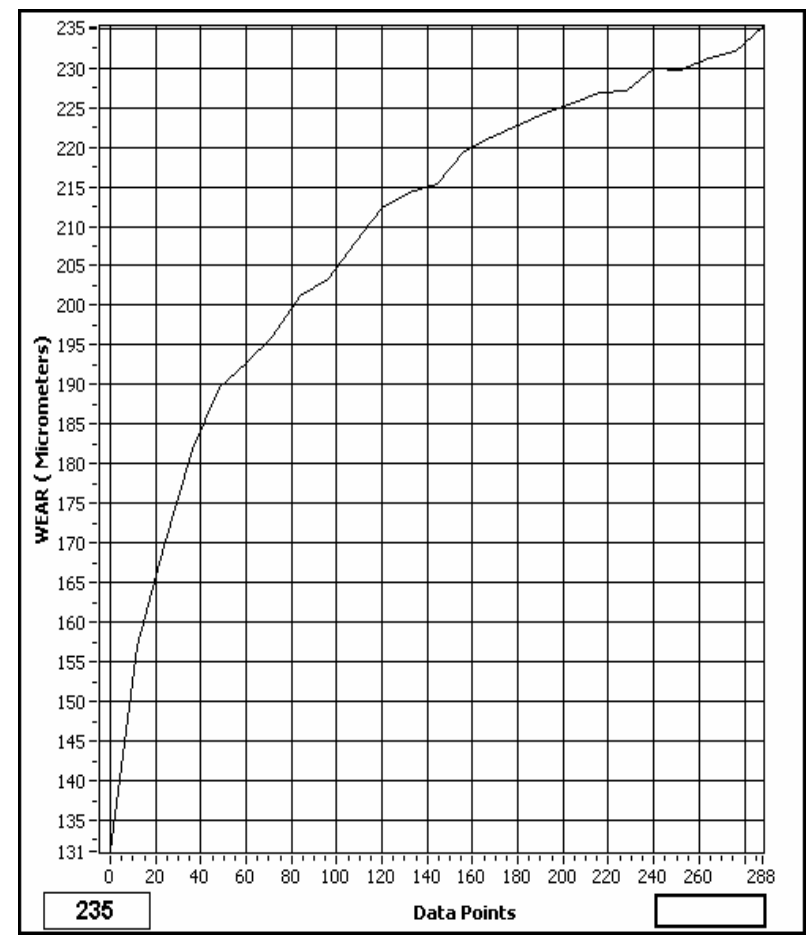

Figure 11. Wear $(\mu \mathrm{m})$ vs Data Points

This graph plotted the wear Behaviour of $98 \% \mathrm{LM}$ 25 aluminium alloy $+2 \%$ nano $\mathrm{Al}_{2} \mathrm{O}_{3}$ versus the data points. It shows a wear of 235 micrometers.
3.2.5 Graphical Representation Of Wear Behaviour: 97.5\%LM 25+2.5\% Nano $\mathrm{Al}_{2} \mathrm{O}_{3}$ Under Load 500g:

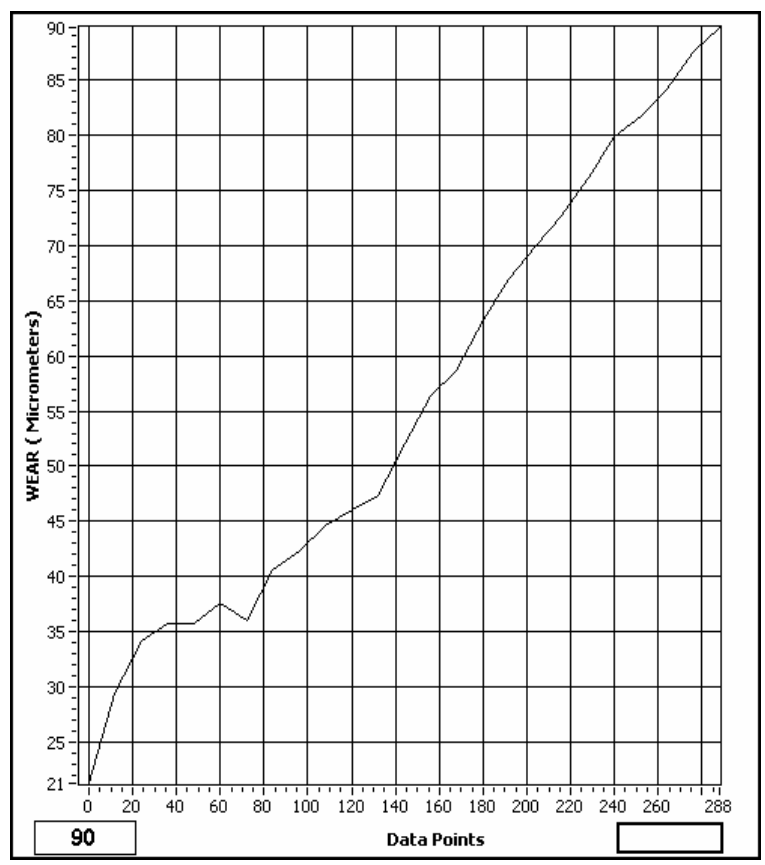

Graph: 10 Wear $(\mu \mathrm{m})$ vs Data Points

This graph plotted the wear Behaviour of 97.5\%LM 25 aluminium alloy $+2.5 \%$ nano $\mathrm{Al}_{2} \mathrm{O}_{3}$ versus the data points. It shows a wear of 90 micrometers.

\section{CONCLUSION AND DISCUSSIONS:}

The composites Material (LM 25-2.5\% $\mathrm{Al}_{2} \mathrm{O}_{3}$ ) exhibited improved wear resistance in comparison with the other tested samples.

Table: 4 Wear Result For Various Specimens

\begin{tabular}{|c|c|c|c|c|}
\hline $\begin{array}{l}\text { s. } \\
\text { no }\end{array}$ & Composition & Time & $\begin{array}{l}\text { Wear(micro } \\
\text { meters) } \\
\text { under effect } \\
\text { of gravity }\end{array}$ & $\begin{array}{c}\text { Wear } \\
\text { (micro } \\
\text { meters) } \\
\text { Loaded } \\
\text { condition }\end{array}$ \\
\hline & Pure LM 25 & 300 & 110 & 1163 \\
\hline & $\begin{array}{l}\mathrm{LM} 25+1 \% \text { nano } \\
\mathrm{Al}_{2} \mathrm{O}_{3}\end{array}$ & 300 & 100 & 258 \\
\hline & $\begin{array}{l}\mathrm{LM} 25+1.5 \% \\
\text { nano } \mathrm{Al}_{2} \mathrm{O}_{3}\end{array}$ & 300 & 90 & 188 \\
\hline & $\begin{array}{l}\mathrm{LM} 25+2 \% \text { nano } \\
\mathrm{Al}_{2} \mathrm{O}_{3}\end{array}$ & 300 & 87 & 235 \\
\hline & $\begin{array}{l}\mathrm{LM} 25+2.5 \% \\
\text { nano } \mathrm{Al}_{2} \mathrm{O}_{3}\end{array}$ & 300 & 71 & 90 \\
\hline
\end{tabular}

The Graph between various composites shows the variation in the wear of pure Aluminium alloy (LM 25) and reinforced LM25 Aluminium alloy with various weight ratios of Nano alumina particulates

From the experimental investigations by preparing and testing of wear specimens consisting of LM 25 alloy reinforced with various proportions of nano alumina and the wear rates were found and tabulated as in table 4.It is found that the reinforcement having a combination of $2.5 \%$ addition of nano alumina shows better wear performances at both loading and unloading conditions: 
1) The wear rate of the graded nano-composite reinforced aluminium alloy material decreased with the increase of nano-alumina in LM 25 aluminium alloy composition.

2) The composition of $97.5 \% \mathrm{LM} 25+2.5 \%$ nano $\mathrm{Al}_{2} \mathrm{O}_{3}$ shows better wear performance comparing other compositions.

3) The wear gets reduced to 71 micrometers and 90 micrometers with the addition of $2.5 \%$ addition of nano-alumina with LM 25 aluminium alloy under unloading and loading conditions respectively.

\section{REFERENCES}

[1] Torralba JM, Costa CE, Velasco F. P/M Aluminum matrix composites: an overview. J Mater Process Technol 2003;133:203-6.

[2] Modi OP, Prasad BK, Vegneswaran AH, Vaidya ML. Dry sliding wear Behaviour of squeeze cast aluminum alloy-silicon carbide composites. Mater Sci Eng A 1992;151:235-45.

[3] Alireza Abdollahi, Ali lizadeh, Hamid Reza Baharvandi. Dry sliding tribological Behaviour and mechanical properties of Al2024-5 wt.\%B4C nanocomposite produced by mechanical milling and hot extrusion

[4] C Xiaoliang Shi, Jie Yao, Zengshi Xu, Wenzheng Zhai, Siyuan Song, Mang Wang, Qiaoxin Zhang . Tribological performance of TiAl matrix selflubricating composites containing Ag, Ti3SiC2 and BaF2/CaF2 tested from room temperature to $600 \mathrm{C}$

[5] Auezhan Amanov, ShinyaSasaki, Dae-EunKim OleksiyV.Penkov, Young-SikPyun Improvement of the tribological properties of Al6061-T6 alloy under dry sliding conditions Tribology International 64 (2013) 24-32

[6] Dehong Lu n, Yehua Jiang, Rong Zhou "Wear performance of nano-Al2O3 particles and CNTs reinforced magnesium matrix composites by friction stir processing www.elsevier.com Wear 305 (2013) 286-290.

[7] "Influence of rotational speed and reinforcements on wear and mechanicalproperties of aluminum hybrid composites via friction stir processing" Devaraju, A. Kumar $\square$, B. Kotiveerachari Materials and Design 45 (2013) 576-585
[8] Sahin, Y. Unlu, B.S. “investigation of tribological and mechanical properties Tribological Behaviour and Wear Surface Analysis of Metal Matrix Composites", Journal of Materials Science, Vol.34, pp.875-880, 1999.

[9] Suresh Kumar, Ranvir Singh Panwar, O.P. Pandey, "Effect of dual reinforced ceramic particles on high temperature tribological properties of aluminum composites" www.sciencedirect.com Ceramics International 39 (2013) 6333-6342

[10] Ali Mazahery, Mohsen Ostad Shabani, "Microstructural and abrasive wear properties of $\mathrm{SiC}$ reinforced aluminum-based composite produced by compocasting“ Trans. Nonferrous Met. Soc. China 23(2013) 1905-1914.

\section{ПОБОЉШАЊЕ ОТПОРНОСТИ НА ХАБАЫЕ ЛЕГУРЕ АЛУМИНИЈУМА ДОДАВАЊЕМ НАНОАЛУМИНИЈУМА}

\section{Р. Сурендран, Н. Манибхарати, А. Кумаравел}

Рад се бави истраживањем понашања при трењу LM25 ојачаног нано $\mathrm{Al}_{2} \mathrm{O}_{3}$, нанокомпозитом са повећаном отпорношћу на хабање. Чвстоћа и густина су постигнуте СТИР ливењем. Произведена су 4 различита узорка нанокомпозита ојачаних додавањем наноалуминијума: 99\%LM $25+1 \%$ нано $\mathrm{Al}_{2} \mathrm{O}_{3}, 98,5 \% \mathrm{LM} 25+1 \%$ нано $\mathrm{Al}_{2} \mathrm{O}_{3}, 98 \% \mathrm{LM} 25+2 \%$ нано $\mathrm{Al}_{2} \mathrm{O}_{3}, 97,5 \%$ LM 25+2,5 нано $\mathrm{Al}_{2} \mathrm{O}_{3}$ са чистом ЛМ легуром алуминијума. Испитивање сувог хабања вршено је на апарату трибометар PIN-ONDISC a перформансе отпора трења су испитиване у условима оптерећења и растерећења. Ојачање нано честица алуминијумском матрицом побољшава механичка и физичка својства и мења морфологију нанокомпозита. Хабање се смањује због формирања јаке везе између $\mathrm{Al}$ и $\mathrm{Al}-\mathrm{Al}_{2} \mathrm{O}_{3}$ нанокомпозита. Резултати показују да додавање нанопраха има утицаја на повећање отпорности на хабање код легуре алуминијума и да се максимално смањење хабања постиже додавањем 2,5\% нано $\mathrm{Al}_{2} \mathrm{O}_{3}$ у поређењу са резултатима добијеним применом чистог LM25 и осталих $\mathrm{Al}-\mathrm{Al}_{2} \mathrm{O}_{3}$ композита. Испитивање хабања је вршено клизањем направљених нанокомпозитних цилиндричних чивија преко челичног диска константном брзином клизања у условима оптерећења и растерећења, са теретом од 500 г. 